\title{
Magic as Technological Dominion: John Dee's Hydragogy and the Draining of the Fens in Ben Jonson's The Devil is an Ass
}

\author{
Todd Andrew Borlik ${ }^{1}$
}

Accepted: 25 August 2021 / Published online: 3 November 2021

(c) The Author(s) 2021

\begin{abstract}
This paper explores the ambiguous role of magic in the controversy over the draining of the fens, the last bastion of wilderness in seventeenth-century England. In what now looks like an early form of environmentalist resistance to the destruction of these wetlands, opponents of the drainage accused the undertakers of invoking diabolical aid in their audacious efforts to tamper with God's creation. Evidence of this mentality can be found in both William Shakespeare's The Tempest and Ben Jonson's The Devil is an Ass. Via a close reading of Jonson's comedy, this paper navigates the confluence of magic, technology, and "projection" in the ideological debate surrounding the fens. Just as the traditional Vice figures (Iniquity and Pug) find themselves out-devilled by Jacobean Londoners, the play dramatizes the appropriation and displacement of a residual poetics of enchantment by the emergent discourses of economics and applied engineering. A tendency to equate magic with hydro-engineering technology may have been encouraged by John Dee's involvement in the project. Drawing on an unpublished manuscript in the Ashmole collection at the Bodleian Library, this paper seeks to uncover the extent and impact of Dee's role in the drainage. Advocates of the drainage, however, not only denied any supernatural involvement but also counterattacked by accusing their opponents of credulity and magical thinking. They characterized the native fen-dwellers as superstitious heathens and cast a scathing eye on local folklore depicting the fens as a demon-haunted wasteland. In pro-drainage documents, the proposed draining of the fenlands becomes tantamount to an exorcism, purging the rural backwaters of paganism and witchcraft. Wetlands management will now be conducted through applied engineering rather than magical incantations. A little known Jacobean ballad, "The Powte's Complaint" (c. 1619) revives these animistic tropes to protest the fen's destruction. Jonson's play may explain why this tactic was doomed to fail and why this poem has been forgotten. As the credibility of magic eroded in the mid-seventeenth century, opponents of the drainage instead sought to stir up public resentment against the foreignness of the Dutch under-takers rather than their supposed collusion with supernatural forces. Jonson's own projection that the drainage
\end{abstract}

Extended author information available on the last page of the article 
was an impossible con (like alchemy) would prove inaccurate. Nevertheless, The Devil is an Ass stands as the one of the most ecologically-engaged texts in the canon of early modern English drama.

Keywords Ben Jonson - Demonic possession · Early modern · Magic · Nature · Fens $\cdot$ John Dee $\cdot$ Ecocriticism

What emboldened so many Renaissance Europeans to presume they had an absolute right to manipulate the environment? The answers to that question are myriad and complex, but Christopher Marlowe's Doctor Faustus (c. 1589) highlights one of the cultural factors propelling the technological take-off of the West. As he opens his necromantic books, Faustus envisions them ushering in a brave new "world of profit and delight/Of power, of honor, of omnipotence." (1993, A 1.1.50-55.). In retrospect, his fantasy of the "artisan" subjecting "all that moves between the quiet poles" to human "dominion" reads like a prophecy of the Anthropocene. ${ }^{1}$ In Marlowe's tragedy, and the magus and demon plays that capitalized on its popularity, the Renaissance stage could be viewed as a platform for voicing the dream of technological dominion over the natural world. Two centuries later, the same necromantic books would inspire Victor Frankenstein, and the German poet Goethe would, drawing upon the same medieval legend as Marlowe, envisage Faust excavating a ditch to drain inland swamps:

A swamp surrounds the mountains' base,

It poisons all I have achieved till now.

I'll drain it too; that rotten place

Shall be my last great project. $(1994, \text { p. } 223)^{2}$

As this article will unfold, similar vaunts resound in Ben Jonson's The Devil is an Ass (1616), in which a "projector" boasts of hydro-engineering schemes to "reclaim" the English fens. Unlike Goethe, however, Jonson does not view this as a humanitarian feat. Nor does he ask his audience to suspend their disbelief in magic. Rather Jonson channels Protestant skepticism about magic to foster disbelief in technological marvels. Guided by new archival material, this article will explore the fens as a key battleground in the seventeenth-century internecine conflict between magic and science, while advancing an ecocritical interpretation of Jonson's comedy as a counter-blast to the Promethean worldview of Faustus.

In the 1960s, Frances Yates (1964) propounded the influential thesis that the Renaissance revival of Hermetic magic was instrumental in kick-starting the technological "will to operate" upon the material world. Isaac Newton devised his laws of physics with his right hand and sought the philosopher's stone with his left; Johann Kepler calculated planetary orbits while drawing horoscopes; John Dee studied

\footnotetext{
${ }^{1}$ For an ecocritical reading of Marlowe's tragedy, see Cless (2010, pp. 69-90).

${ }^{2}$ Heather Sullivan notes that his attempt to stop the flows of nature coincides with Faustus's death (2011, p. 246).
} 
geometry during the day and conversed with angels at night: "thou desirest use," a spirit told him, and "I teach use". The persistence of magical thinking among early modern intellectuals has led Brian Copenhaver to pose the eye-popping question: "Did science have a Renaissance?" (Cophenhaver, 1992; Rossi, 1968; Shumaker, 1972; Stivers \& Stirk, 2001). Over the past half-century, however, some significant caveats have been raised with the Yates thesis. Robert Westman and J. E. Maguire retorted that Hermeticism played a minimal role in the Copernican Revolution, and did little to spur the quantitative analysis of empirical phenomena. Brian Vickers has insisted that while occult and scientific mentalities co-existed, they were not symbiotic. Calling for greater nuance, Nicholas Clulee contends that different branches of magic had different implications for different scientific disciplines. The implications are not always clear even in the same branch: if Francis Bacon could praise alchemy as proto-chemistry in The Advancement of Learning (1605), Ben Jonson's The Alchemist (1613) could ridicule it as a preposterous con. Given the sheer messiness of the evidence, Stephen Clucas wisely cautions against clinging to grand narratives about the relationship between magic and science. Instead he encourages historians to examine the "praxiological localities" where they collided-that is, specific places where theory gave way to practice (Wistman \& McGuire, 1977; Vickers, 1984; Clulee, 1988, p. 240; Clucas, 2003, p. 52). Following that prescription, this paper conducts an ecocritical re-examination of the vexed relationship between magic and science in the English fens. This is, I believe, a "praxiological locality" of some import, as the destruction of these wetlands has been dubbed the greatest environmental disaster perpetrated in English history.

To better capture the ambiguous status of magic in early modern representations of the fens, this study will garner evidence from an eclectic mix of sources. It charts the enchanted topography of the fens in medieval legends, fenland folklore, folk medicine, and an obscure protest ballad. Conversely, this chapter also attempts to explain why fen-dwellers would have conflated applied science with occult magic by turning to Shakespeare's The Tempest (1611), a 1622 manuscript letter describing resistance to the drainage, and the writings of John Dee. An unpublished manuscript by Dee now at the Bodleian Library presents equivocal evidence for the Yates thesis. If occult beliefs encouraged confidence in the power of human ingenuity to conquer the fens, critics of the enterprise could also appeal to magic to indict scientific hubris. The controversy over the fens thus affords an edifying case study of how magic functioned as a problematic metaphor for technological dominion over nature.

Finally, the article pools these resources as context for an eco-critique of Ben Jonson's The Devil is An Ass, the play that mostly directly addresses the controversial plans to drain the wetlands. Its plot centres on a naïve Norfolk gentleman named Fitzdottrel who is obsessed with conjuring devils and duped into investing in development schemes to reclaim the fens. Laughter in the play might appear to drive a wedge between magic and science, between provincial and metropolitan, between the credulous medieval and the shrewder early modern eras. This essay proposes that the comedy is in fact far more complex. Characterizing Jonson's style as "diabolical realism," I will argue that this modern morality play perpetuates the confusion of demonology and technology that it seemingly denies to expose the dream of human dominion as hubristic and venal. 


\section{Demonizing the Fens}

It makes perfect sense that magic would flourish in a daunting and volatile environment such as the English fens. Prior to the drainage, the fens comprised an enormous checkerboard of low-lying wetlands in and around the Wash estuary. Encompassing nearly 1300 square miles, they stretched from King's Lynn in the east to Peterborough in the west, from Ely and Cambridgeshire in the south all the way to Hatfield Chase and the Isle of Axholme on the Yorkshire border. Much of this region barely rises above sea level, and in 1600 consisted of a mixture of shallow lakes, mudflats, sodden peat, and tidal creeks, dotted with uplands known as "edges" and "islands." Ecologists today recognize the value of such wetlands as a precious habitat for a teeming variety of insects, fish, and birds. ${ }^{3}$ In the medieval and early modern periods, however, outsiders tended to regard them as a breeding ground for demons.

One of the earliest extant accounts of the haunted fenscape is the Life of St Guth$l a c$, compiled by Felix the Monk in the eighth century. Guthlac was an Anglo-Saxon hermit who took up residence on the remote fen island of Crowland in southern Lincolnshire. Felix's hagiography memorably captures the terror evoked by terra infirma. Again and again, Guthlac finds his devotions interrupted by "horrible troops of foul spirits" (Colgrave 1956, pp. 101-103). They steal his psalter and drop it in the water, or afflict him with insomnia by hissing and screeching all night outside his hut. One night a legion of grotesquely misshapen devils seizes hold of the hermit and drag him through brambles before dunking him in the filthy fen-water. Victorian historians would dismiss these episodes as malaria-induced hallucinations or as mythologized recollections of his scuffles with British brigands. In his triumphant History of Embanking and Draining the Fens (1662), William Dugdale would cite these legends as proof the ungodly nature of the wetlands: "the horrour of [the] place is lively represented in the story of S. Guthlake" (p. 179).

The Witch of Brandon who figures in the saga of Hereward the Wake would also have fed the metropolitan perception of the fens as a hotbed of dark magic. According to the Gesta Herewardi (c. 1110-30), the Normans employed a local cunning woman to perform ritual curses against the English freedom-fighters who had taken refuge on the Isle of Ely. Mounting a battlement on the siege lines, the woman began "casting spells for their overthrow; and at the end of her chattering and incantations she bared her arse at them" (Swanton et al. 1997, p. 25). Dugdale reproduces this lurid tale as well in his apology for the drainage. Though he is swift to denounce this "wicked sorceress" and her "devilish art" (1662, pp. 190-91) his telling confirms his dim view of the fens as a heathenish backwater, thereby justifying their destruction. In the seventeenth century, such tales were more than just the stuff of hoary legend. In a 1637 trial of fenland rioters who had sabotaged drainage works near Wisbech, a woman branded as "the first mover of this mutiny" was accused of witchcraft. Like

\footnotetext{
${ }^{3}$ One of the few spots unscathed by the drainage, Wicken Fen, gives an idea of the bio-diversity these wetlands support. Preserved by Cambridge entomologists in the early twentieth century, this small parcel of fenland is home to 300 flowering plants and over 5000 insect species, including 700 butterflies and 200 spiders, six of which are found nowhere else.
} 
a latter day descendent of the Witch of Brandon, she was suspected of having performed maleficium to curse the undertakers (Lindley, 1982, p. 92).

With so few churches and so many "isles" cut off during the winter by the floods, the fens fostered a microculture where greater credence in magic might linger, even well after the Reformation. Many outsiders would thus have seen a link between "reclaiming" wetlands and saving souls. The author of a 1629 pro-drainage tract bemoans that the local populace has "no means to baptize a child, or to administer the communion, no supply of any necessity, saving what those poor desolate places can afford" (H. C., 1629, A3v). When Matthew Hopkins, the so-called Witchfinder General, visited the Isle of Ely in 1646 he interrogated no fewer than seventeen people accused of witchcraft. Three of the accused witches-William Watson and John and Bridget Bonham of Sutton-had been involved in a protest against the enclosure of the nearby West Fen in the 1620 s (Gaskill, 2007; Young, 2013). It is tempting to speculate that their resistance to the drainage made them suspect: surely only someone allied with the devil would wish to preserve such a savage ecology. In 1698, a Yorkshire antiquarian paid a visit to the Isle of Axholme and described it in his diary as "a mighty rude place before the drainage, the people little better than heathens" (de la Pryme, 1870, p. 173). Evidence suggests that traditional beliefs in magic did not evaporate overnight. In the late nineteenth century, the folklorist M. C. Balfour made numerous visits to this same isle and recorded local legends about moon worship and a curious fen bogey named Tiddy Mun — "tiddy" being a Lincolnshire dialect word for tiny and "mun" a regional pronunciation of man (1891, pp. 145-70). This dwarfish, hirsute, grey-cloaked goblin lived in the meres and would emerge only on misty nights. When the uplands flooded, a group of cottagers (led by a cunning woman) would march outside on the night of a full moon and chant a spell to make the waters to recede. The tale indicates how sympathetic folk magic might function as a primitive means of environmental management, motivated by a desire for equilibrium rather than dominion. When the Dutch arrived and drained the fens, however, Tiddy Mun grew angry and conjured pestilent mists from the black-pools. Such tales suggest that magical beliefs, rather than promoting applied science, could channel resentment of technological interference by outsiders. Whether or not Balfour uncovered an oral tradition dating back time out of mind, a considerable body of research has corroborated her picture of the fens as a magic-ridden place (Barrowclough, 2014; Hutton, 2016; Porter, 1969).

Early moderns would also have been likely to sniff out witchcraft in the widespread use by cunning women of folk remedies against the ague. One spell that worked by sympathetic magic involved staking rods into the ground, lighting them on fire, and chanting: "as the rods burn, so let the ague burn too." Other remedies called for the sufferer to tie locks of hair to a tree, swallow a spider wrapped in a raisin, eat cobwebs, or drink urine (see Rotheram, 2013, p. 29). ${ }^{4}$ As the etymology of the word mal-aria reveals, the "bad air" in the dank wetlands was thought to spawn this disease. Today, we know it be transmitted by the plasmodium parasite.

\footnotetext{
4 Scientists now speculate that malaria could reappear in Britain by 2050 due to Global Warming (Kuhn et al, 2003).
} 
Before malaria was explained in scientific terms, however, those suffering from it could easily be perceived as having fallen victim to an evil spell or a demon. Indeed, it would probably be difficult to persuade an early modern cottager that a demon and a plasmodium parasite are radically different creatures. Though Tiddy Mun's curse afflicted locals as well, many of those born and bred in the fens would have acquired immunities to the disease. Outsiders, such as the undertakers and Scottish labourers brought in to dig the embankments and drains, would have been particularly susceptible. No wonder rumours spread that the fen dwellers were allied with supernatural forces.

With their incantatory rhythms, songs and ballads composed to protest the drainage could also have encouraged the perception of the fen folk as witches. There is a decidedly magical odour to a rare extant specimen of this genre entitled "The Powte's Complaint." One of the striking features of this song is its preponderance of speech-acts in the form of prayers and curses. No fewer than four deities are invoked to jinx the undertakers.

But Ceres, thou behold us, let wild oats be their venture,

$\mathrm{O}$ let the frogs and miry bogs destroy where they do enter. ${ }^{5}$

Since Ceres was the Roman goddess of agriculture, one might expect her to side with the projectors, who were transforming the boggy wetlands into arable farmland. But the song, adopting the perspective of a "pout" (probably an eel-like fish known as the burbot), instead allies her with the amphibious ecology of the fens: the "frogs and miry bogs." The second curse beseeches Aelous to "send a blast" at the undertakers "that they in haste may work no good conclusion." Next the speaker calls on Neptune to "send thy sands to make dry lands when they shall want fresh water." Finally, the ballad prays to the Moon to "send a flood" to re-drown the fens. In a 1685 epic poem championing the drainage, the author (possibly Samuel Fortrey) urges the undertakers to "take no heed/ Of] those that curse your generous labors" $(1685,73)$. Situated alongside the "Powte's Complaint," that line may have a literal application.

Cursing was a common form of social protest in early modern England and was believed to possess a special efficacy when uttered by the poor (cf. Wordsworth's "Goody Blake and Harry Gill") (Thomas, 1971, pp. 506-507). It would be rash to assume, however, that this ballad was composed by an illiterate fisherman, reedcutter, or cunning woman. Though Dugdale printed it without attribution in 1662, I have uncovered four different manuscripts of it at the British Library containing clues as to its authorship, readership, and date (Borlik \& Egan, 2018). Several of the manuscripts originate in Cambridge, while the allusions to the Ceres and Neptune would seem to point to at least a semi-educated author and should not be taken at face value as proof of the persistence of ancient Roman cults among the fen folk. Nevertheless, if the Roman deities command no more belief than the inhuman persona of the talking fish, it does not follow that the anger voiced in the lyrics is any less real. Magic is sometimes a tactic of the disenfranchised or powerless, but the

\footnotetext{
${ }^{5}$ A transcription of the ballad is printed in Dugdale (1662, pp. 391-92).
} 
opponents of drainage did more than just curse. Stirred by speech-acts in ballads like the "Powte's Complaint," they instigated lawsuits and sabotaged the dikes and pumps. They also hurled the accusation of witchcraft back at their accusers. Prior to modern notions of environmental ethics, occult magic could provide early moderns with a vocabulary for stigmatizing technological interference in the natural world.

\section{Demonizing Technology}

If outlanders viewed the fen-dwellers as heathenish yokels, many locals looked upon the drainage as a diabolical undertaking. Proposals to drastically and permanently alter the landscape would not only rob the cottagers of their commons but also reeked of hubris. To critics of the drainage, the difficulty of the undertaking was proof of its immorality: as the antiquarian (and teacher of Ben Jonson) William Camden remarked, "many think it the wisest and best course ... not to intermeddle at all with that which God hath ordained" (1610, p. 492). Intermeddling with the perceived natural order of things is of course a textbook definition of magic. At a meeting of the Commission of Sewers in Peterborough in 1622, one observer noted, "the people think the Undertakers will work by witchcraft, no persons of experience supposing their designs possible." ${ }^{\prime 6}$ Locals were particularly incredulous that the fens could be drained without rendering the rivers and waterways unnavigable. The same observer reports a rumor current in the town of Wisbech that the undertakers would conjure a "spirit" to sink the river:

All men shall haue Warninge that might to keepe their doores fast shutt: I thinke Least the Spirit by Whose power the River is suncke shoulde enter their Houses, and sincke them alsoe. Although I beleeue none of all this, yet I doe note hereby, that men not findinge anie reason howe they should performe their large promises, doe attribute to the divell, What they thinke man cannot doe (f. $152 \mathrm{v})$.

Interestingly, the same anonymous letter records that the Bishop of Peterborough had claimed the undertakers "would do it by conjurac[i]on" (f. 152v). In other words, it was not just the uneducated peasantry that perceived technological overreach as demonic magic.

It should be noted that small-scale "improvements" had been carried out in the fens since Roman times, and continued on an ad hoc basis throughout the Middle Ages. In the Tudor period, the Commission of Sewers encouraged the maintenance of the current embankments rather than construction of new ones. This was the line taken by most fen-dwellers in the seventeenth-century such as the anonymous author of The Anti-Projector (c. 1642), who thought the terrible floods in recent years had been due to the neglect of existing infrastructure. As this suggests, it was not the

\footnotetext{
6 Anonymous to Anonymous. March (1622). MS State Papers Domestic James I 1603-40. SP 14/28 f. 149. National Archives of the UK. State Papers Online. Web. 11 March 2016. I am grateful to Clare Egan for her help in transcribing this manuscript.
} 
notion that humans might reshape the fen-scape that sparked protest; rather it was scale of the re-shaping to abet enclosure of commons and the use of new-fangled, foreign technologies, particularly those developed by the Dutch, which troubled the local population. Resentment of what might be called a kind of technological colonialism led them to equate the drainage with magic, in accordance with Arthur $\mathrm{C}$. Clarke's famous Third Law. ${ }^{7}$

One of the best examples in Renaissance literature of Clarke's Third Law is Shakespeare's The Tempest. As I have suggested elsewhere, the play wades into contemporary debates over the draining of the fens (Borlik, 2013). It seems highly likely that Shakespeare based some aspects of the plot on the life of the demonqueller Guthlac, who may have been the subject of a lost play staged at the Rose in 1594. Caliban bears more than a passing resemblance to the monstrous devils pictured in the Vita Guthlaci and who have a memorable cameo in William Camden's Britannia. In his first appearance, Caliban enters cursing:

As wicked dew as e'er my mother brushed

With raven's feather from unwholesome fen

Drop on you both! A southwest blow on ye,

And blister ye all o'er!

The speech glances at the fen folk's reputation for witchcraft. Caliban recalls his mother's use of sympathetic magic, playing on the contemporary fear that fenland witches could infect people with the malarial fever endemic in the region. His summoning the "southwest" wind to "blister" Prospero would be echoed in the appeal to Aelous in the "Powte's Complaint" to "blast" the undertakers. Caliban's mother, Sycorax, possesses the power to control "ebbs and flows" just like the wise woman described by Balfour's storyteller.

If Caliban and Sycorax represent the fen folk and their popular magic, Prospero embodies the drainage engineers whose projects confounded learned magic with applied science. In a speech echoing that of Ovid's Medea, the magus commands "elves of ... standing lakes" and spirits that chase the "ebbing Neptune." In other words, Prospero boasts of a magical dominion over the elements much like the technological dominion over water and earth claimed by the projectors. In the eyes of a rural cottager, the earth-shaking projects of the Commission of Sewers to "control ebbs and flows" might seem tantamount to sorcery. In the Masque scene, Prospero summons Ceres to bless the marriage of Miranda and Ferdinand, conjuring a vision of "rich leas" of grains and "banks with pioned and twilled brims"- that is, channels that have been dug (pioned) and embanked exactly like those hydro-engineering works currently being installed to drain the fens. Whereas the "Powte's Complaint" implores Ceres to curse the undertakers, Shakespeare has Ceres bestow her blessings

\footnotetext{
7 "Any sufficiently advanced technology is indistinguishable from magic" (Clarke 1962, p. 36). A similar situation occurred at a copper mine in Keswick in the 1560s, when the English harboured suspicion towards the German miners brought over to supervise because of their practical expertise. See Ash (2004, pp. 19-54). Ash's excellent 2017 study on the fens documents local resentment of the Dutch engineers, but does not examine the role of magical thinking or witchcraft in the drainage debates.
} 
on this enterprise. She brings "earth's increase and foison plenty" to the supposedly barren fens. As one would expect of a scene written to be performed before the Stuart court, the masque celebrates the proposed technological transformation of these idle wetlands into an agricultural cornucopia. But Caliban's blistering denunciation of Prospero for usurping his island echoes the fen-dwellers' complaints about the theft of their commons. In depicting the colonizer of the isle as a learned magus, The Tempest caters to critics of the drainage who smeared the undertaking as sorcery. Prospero's decision to abjure his "rough magic" may reflect contemporary feelings of uneasiness about the assumption of technological mastery over nature. Shakespeare's attitude to the drainage is thus characteristically ambivalent.

Rumours that the undertakers would "work by witchcraft" may have been sparked by the involvement of John Dee, sometimes regarded as a model for Prospero (Yates, 1979, pp. 186-192). A previously unexamined manuscript in Dee's hand shines a light on his part in the most concerted assault on wilderness in English history. The backstory is as follows. The exceptionally wet summers the mid-1590s wrought havoc in the fens. Flooding would have been widespread and uplands that normally dried out during the summer remained underwater and could not be used for pasture. In late 1599 some inhabitants of Deeping Fen and surrounding towns petitioned the Queen to repair the banks along the River Welland and River Glen to reduce the flooding. ${ }^{8}$ This prompted the passage of the General Drainage Act of 1600. Shortly thereafter, the Commission of Sewers appointed a man by the name of Captain Thomas Lovell to undertake the project. The cost was quoted at a staggering $£ 12,000$. Many of the free-holders supposed to fund the scheme refused to contribute, so Lovell had to finance it out of his pocket. In return for his pains, Lovell was to receive one-third of the drained land (approximately 15,000 acres). After initial delay over apportioning the lands, the project did make some headway. In 1607, John Norden, declared "much of [the fen-land] is made lately firm ground by the skill of one Captain Lovell and by M. William Englebert, an excellent Engineer. And truly it is much to their own commendation, and to the common good of the inhabitants near" (Norden, 1607, p. 189).

Not everyone, however, was as thrilled as Norden. In a Star Chamber case of 1603, a Thomas Welles of St. James Deeping was accused of inciting a group of sixteen locals to destroy the drainage works and reportedly threatened to "bury Lovell in one of his own ditches" and maim or murder anyone who assisted him (Lindley, 1982, p. 34). Whether frustrated by these acts of sabotage or whether he simply ran out of money, Lovell eventually abandoned the project. ${ }^{9}$

At some point during this process, Lovell decided to consult John Dee. Although Dee's manuscript is undated, it seems a reasonable conjecture that it would have been written sometime between Lovell undertaking the project in

\footnotetext{
${ }^{8}$ An anti-drainage pamphlet would claim that such petitions were not presented on behalf of the local community but in fact by agents of the projectors' own "faction." The Anti-Projector (c. 1646), 2. Also see John Maynard, A Picklock of the Old Fen Project (1650).

9 According to Dugdale, Lovell's project foundered "in regard of the unseasonableness of the times [bad weather] and riotous lets and disturbances of lewd people, casting down his banks" (1662, p. 207).
} 
1600 and Dee's death in late 1608. But why would Lovell ask for Dee's assistance? An obvious answer can be found in Dee's famed Mathematical Praeface to the Elements of the Geometrie of Euclid. Among the new sciences Dee claims Euclid's textbook will spawn is "Hydragogie." Though scholars have pegged this section of the preface as a fanciful list of "jabberwocky disciplines," hydragogy is clearly nothing more than Dee's neologism for what we would now call hydroengineering (Shumaker and Heilbron 1978, p. 31):

Hydragogie demonstrateth the possible leading of water by nature's law, and by artificial help, from any head (being a spring, standing, or running water) to any other place assigned (Dee, 1570, D1v).

Dee speaks of the "marvelous forcing of water to ascend," and identifies several methods of doing so, "either by tympane, kettle mills, skrue, ctesibike [Ctesibius], or such like, in Vitruvius, Agricola (and other) fully the manner may appear" (Dee, 1570, D2v). The sources Dee mentions, Vitruvius and Agricola, suggest that Dee's "hydragogie" is informed more by applied technology than occult magic.

This impression is confirmed by a study of Dee's manuscript on draining and embanking the fens. He describes his task as follows:

Learne in the fennes what woorkes have ben done and the chardges thereof.

What woorkes they would have don and what they would give: and what the same are

woorthe. Wheare the water shold have ben

turned oute theyr landes.

Whether ever the lyke woorke have ben heretofore and as muche of the chardge and circumstance

thereof as are possible to be had (MS Ashmole 242. Fol. 156-61).

At one point Dee mentions deploying a "dubble strong cable" to plumb the depths of the meres and claims that by submerging "turfe or clay a foot thick in water an inch deep "the water will ascend ... and clyme up to the toppe in one nyght or very neere." Clearly, these are technological operations; no angelic conjuring such as Dee elsewhere indulged in was involved (Harkness, 1999). This is the "hydragogie" that Dee speaks of in his Praeface. Another manuscript by Dee written in 1553 at the request of the Duchess of Northumberland reveals the "True cause and account (not vulgar) of Floods and Ebbs" (Cooper, 1861, vol. 2, p. 506). Unlike Chaucer in "The Franklin's Tale," Dee here explicitly seeks to dissociate the observational science of calculating tides from magical thinking. The latter is also absent from his manuscript on the fens. Dee is not troubled by any devils but by the presence of "noysom varmins": the "casting of wormes, of beatles, flyes, myse" that exacerbates "the dampe of the soyle." He attributes "murreins" or diseases among the cattle to boggy pasture not the maleficium of witches and their demonic familiars. In his introduction to Euclid, Dee attempts to distance his mathematical endeavors from magic, protesting that those who contrive mechanical feats should not be slandered as 
conjurors: "How great is the blindness \& boldnes of the multitude in thinges aboue their capacity?" (Dee, 1570, A2r). No doubt Dee would have dismissed the charges of witchcraft against the drainers as another example of the ignorance of the masses. The bundling of this manuscript on drainage technology alongside alchemical treatises in Ashmole's collections, then, seems somewhat misleading.

Or is it? Despite Dee's disclaimer, many scholars refuse to accept a tidy distinction between magic and applied science in the worldview of this Elizabethan magus. In the first proper academic monograph on Dee, Peter French attributed the technophilia of the Mathematical Praeface to his fascination with magia. William Eamon captures the hybrid quality of the Praeface when he labels it as a "mathematicomagical interpretation of technology" (French, 1972, p. 90; Eamon, 1983, p. 199). Subsequent studies have corrected Yates' overemphasis on the Hermetic tradition, yet many still concur that insofar as natural magic was more pragmatic or "insistently naturalistic" it galvanized the ambitions and even the methods of modern science (Clulee, 1986, p. 58; Mebane, 1989, p. 85; Clark, 1999, p. 220; Szonyi, 2010). Through understanding and commanding invisible forces in nature, the scientistmagus could transform the environment to improve the human condition. This core conviction of Dee's helps account for his willingness to aid Thomas Lovell in the fens. But Lovell's failure highlights a danger lurking in this analogy between magic and science. The study of magic could also inspire overconfidence in the power of technology to remedy all earthly ills. Yates' claim that belief in magic stimulated scientific research has a flip side: that is, the debunking of magic as mere illusion could generate skepticism towards technology. Even worse, the assumption of a godlike authority over nature could, despite Dee's protestations, be branded unlawful or demonic. This pattern is exactly what unfolds in Ben Jonson's The Devil is an Ass, the most explicit commentary on the fen-draining controversy in English drama.

\section{Demonology and Technology in The Devil is an Ass}

Once regarded as the first of Jonson's "dotages," The Devil is an Ass has undergone a critical reappraisal over the past few decades and is now hailed as a "neglected masterpiece" or a "natural climax" to Jonson's early career (Dutton, 2000, p. 67; Parr 2012, vol 4, p.467). Rather than a symptom of his waning powers as a dramatist, the 10-year hiatus from playwriting that followed it could be construed as a frustrated withdrawal in response to the offense it apparently provoked. Thanks to incisive work by Leah Marcus, Robert C. Evans, and (most notably) Julie Sanders, the comedy's satire on fenland politics is well known among Jonson scholars (Marcus, 1989, pp. 99-102; Evans, 1994, pp. 74-77; Sanders, 1998, pp. 107-22). Expanding on these studies, the remainder of this chapter will frame the play's critique of the drainage schemes as part of cultural negotiations between magic and applied science in the early seventeenth century. This focus on demonology and technology not only helps knit together the two plots of Jonson's comedy, but also enables us to view it through an ecocritical lens while maintaining a degree of historical rigor.

Some of his contemporaries apparently failed to appreciate Jonson's scathing commentary on the fen project. In a conversation with William Drummond, 
Jonson reported that he had been "accused" about the comedy, and that "the King had desired him to conceal it" (Herford, Simpson, and Simpson 1925-52, vol. 1, pp. 143-44. Also see Happé, 1994, pp. 3-4). Admittedly, Drummond's notation is somewhat ambiguous. Assuming Jonson would have removed the offensive content (which is debatable), Ian Donaldson speculates that it may not have pertained to the drainage per se but could simply have been an ad hominem attack on a particular courtier (2011, p. 344). But the latter does not preclude the former; several prominent figures at the Jacobean court were scrambling to make a mint from recovering the drowned lands. On 11 August 1614, James granted the rights to drain and enclose the fenland owned by the crown to Sir Robert Carr and Thomas Reade. Leah Marcus has argued that the Robert Carr mentioned here is not James' notorious favourite, the Earl of Somerset, but his identically named cousin, a Gentleman of the Prince's Bedchamber (1989, pp. 99-102). ${ }^{10}$ This Robert Carr (or Kerr) had danced in Jonson's masque The Golden Age Restored in 1615 (Riggs, 1989, p. 244). When Jonson was composing The Devil is an Ass in 1616, Kerr's more illustrious cousin had been implicated in the murder of Sir Thomas Overbury. During this sensational celebrity trial, it emerged that Carr's wife, Frances (née Howard), had paid to have spells cast on her former betrothed, the Earl of Essex, and on Overbury for opposing her marriage to James' favourite (Lindley, 1993). The fact that Carr's cousin with the exact same name had received a royal patent to drain fens would have fed suspicions that the movers and shakers behind the project were depraved aristocrats in league with diabolical forces.

Though this trial appeared to confirm the existence of witchcraft, other law cases at the time exposing fraudulent exorcists would have bred cynicism. Jonson alludes to these scandals when the undertakers persuade Fitzdottrel to feign demonic possession on the basis of others who managed to fool the public:

Did you ne'er read, sir, little Darrel's tricks,

With the boy o' Burton, and the seven in Lancashire,

Sommers at Nottingham? All these do teach it. (Parr 2012 , vol. 4, 5.3.6-8).

In a landmark essay, Stephen Greenblatt demonstrated how the supernatural energies unleashed in these forbidden Catholic rituals were re-channelled into the playhouse (Greenblatt, 1988, pp. 94-128). In The Devil is an Ass, arguably an even better example than King Lear of the Protestant debunking of exorcism as theatre, Jonson makes a parallel observation about the sublimation of magic into science. At the start of the play, the naïve Fitzdottrel has been conjuring demons in the hopes they will lead him to "hidden treasure" (1.5.17). He is soon persuaded by two con men - on the basis of their miraculous technology - to invest in land development schemes in the fens that promise to make him one of the richest men in England. Fitzdottrel proves to have swapped one superstition for another.

In the opening act, Jonson imagines a devil from a medieval morality play thrust into a Jacobean city comedy. The play thus presents itself as a meditation on the

\footnotetext{
10 Another courtier invested in drainage schemes was the Lord Chief Justice John Popham, who had interrogated Jonson in 1601 over charges of libel in his play Poetaster (Sanders 1998, pp. 113-14).
} 
rupture between the medieval and the early modern, between rural and urbane epistemologies. Since Fitzdottrel hails from the fenland region of Norfolk, his fascination with demons could be chalked up to provincial superstition. Other works by Jonson reveal he was familiar with the fens' reputation for dark magic. In the Masque of Queens from 1609, the witches report they have arrived "from the lakes and from the fens" (7:84). Notably, in his unfinished Sad Shepherd, Jonson pictures the Witch of Papplewick.

steal[ing] forth to relief in the fogs

And rotten mists, upon the fens and bogs

Down to the drownèd lands of Lincolnshire,

To make ewes cast their lambs, swine eat their farrow. (2.6.24-27).

These are the same "drownèd lands" over which Fitzdottrel hopes to be Duke. ${ }^{11}$ As this essay has argued, portrayals of the fens as a haven of witchcraft might conspire to justify the draining. Such passages must give us pause before attributing a firm ecological orientation to Jonson's work. In The Devil is an Ass, Jonson could be seen as promoting a poetics of disenchantment that aligns the comedy with the metropolitan outlook of scientific modernity. But a close reading of the comedy suggests Jonson is not rejecting the morality tradition in favor of city comedy so much as fusing the two. Jonson's "diabolical realism" (to borrow a phrase from J. L. Simmons) depends upon an outmoded moral framework — like Bulgakov's The Master and Margarita (1967) - to sharpen the perception of wickedness that might otherwise pass undetected or under-loathed (Simmons, 1980). While denying the existence of literal demons, his satire conspires to demonize the fen-drainers.

When he arrives in London, the devil Pug, despite his worst intentions, soon finds himself outfoxed or rather out-devilled by the amoral Londoners. Two of the most despicable are Engine, whose name links him with technology, and Merecraft, described as a "projector." This profession puzzles Fitzdottrel:

FITZDOTTREL But what is a projector?

I would conceive

ENGINE Why, one, sir, that projects

Ways to enrich men, or to make 'em great,

By suits, by marriages, by undertakings

According as he sees they humour it

FITZDOTTREL Can he not conjure at all?

Fitzdottrel's confusion may be laughable but Jonson uses it to make a serious point: projecting was not unlike conjuring in its attempt to divine the future. The

\footnotetext{
11 As a former pupil of William Camden, Jonson could possibly have heard tales of Guthlac and the haunted Lincolnshire fens from his teacher, who describes Crowland in Britannia (1586, 1610). For more on the local topography of the play, see Sanders (1999, pp. 49-68).
} 
word itself had occult connotations. As the author of The Alchemist knew, "projection" was originally a technical term in alchemy for casting ingredients into a crucible or cauldron. It only began to signify something like venture capitalist- "one who plans or designs an enterprise or undertaking" in hopes of profit-in 1596. According to the OED, the term first acquired the pejorative meaning of confidence man in 1615, the year before The Devil is an Ass.

The projector's get-rich-quick scheme proves to be a plan

for recovery of drowned land,

Whereof the Crown's to have his moiety

If it be owner; else, the Crown and owners

To share that moiety, and the recoverers

T'enjoy the tother moiety for their charge. (2.1.45-49)

This passage indicates the playwright paid close attention to actual financial arrangements for reclaiming the fens: the first scenario mirrors James' agreement with Robert Carr and the second gestures at a deal struck with the Earl of Argyll. ${ }^{12}$ Jonson makes it clear these schemes will not benefit the locals or even the smallscale investors. Merecraft boasts they will scam "citizens, commoners, and aldermen" by having them finance the venture and then "blow "em off again,/Like so many dead flies, when "tis carried" (2.1.42-44). Unsurprisingly, Fitzdottrel is going to be fleeced as well. He is seduced by the promise of fabulous wealth and a ludicrous title: the Duke of Drowned Land.

The play thus forges a link between naïve belief in demons and irrational faith in Baconian technocracy. When Mistress Fitzdottrel laughs at her husband's credulity, he tells her to "have faith" and rebukes her as "an infidel" (2.3.39). These lines figuratively equate techno-skeptics with religious unbelievers. She retorts that he trusts too much in these "false spirits" (2.3.43), a phrase that associates the projectors with devils. Earlier in the play, Fitzdottrel failed to recognize Pug as a demon because he did not have a cloven foot. That is, he cannot see evil right in front of him because he expects it to look like its clichéd image in paintings and in stageplays like Marlowe's Faustus. Mistress Fitzdottrell has here distilled the moral of Jonson's inverted allegory: the superstitious who believe in mythical demons fail to perceive the real but banal wickedness in their midst. Her husband, however, interprets her words in a literal sense. His response betrays defensiveness towards accusations that the fens could only be drained by witchcraft:

Spirits? Oh, no such thing, wife! Wit, mere wit!

This man defies the devil and all his works!

He does't by engines and devices, he!

He has his wingèd ploughs that go with sails

Will plough you forty acres at once! And mills

Will spout you water ten miles off! All Crowland

Is ours, wife; and the fens, from us in Norfolk

$\overline{12 \text { On Argyll as a possible target }}$ of Jonson's satire, see Evans (1994, pp. 74-77). 
To the utmost bound of Lincolnshire! (2.3.44-51)

The speech attempts to draw a cordon sanitaire between the Devil's "works" and "engines and devices." But the play as a whole suggests the impossibility of this feat; one of the humanoid demons in this modern morality play is, after all, named Engine.

This denial is also ironic because Fitzdottrel is hardly a rational skeptic. As previously mentioned, at the start of the play he confesses to conjuring devils and having hired the best "artists" from Oxford and Cambridge to raise him (without success). He rattles off a name of infamous quacks, astrologers, and conjurors in early modern London purported to have conversed with him: Thomas Bretnor, Edward Gresham, Simon Forman, James Franklin, Nicholas Fisk, and Abraham Savory. Conspicuously absent from this list is John Dee. Since it has long been thought that Jonson lampooned Dee's partnership with Edward Kelley in The Alchemist, this omission invites scrutiny. ${ }^{13}$ Fitzdottrel exclaims that if the devil would deign to appear he would willingly share his wife with him in what sounds an awful lot like a swipe at the wife-swapping Kelley claimed the Angel demanded of them during one of their séances. This connection seems particularly inviting considering that Dee was personally involved in the project to drain the fens. As revealed by the manuscript at the Bodleian, Captain Thomas Lovell consulted Dee about embanking the fens around Crowland in southern Lincolnshire-the very spot mentioned here by Fitzdottrel.

A comment by Merecraft suggests Jonson knew of these previous attempts to drain the Lincolnshire fens:

I'll begin at the pan,

Not at the skirts - as some ha' done, and lost

All that they wrought, their timber-work, their trench,

Their banks all borne away, or else filled up

By the next winter. (2.1.53-57)

These lines almost certainly allude to Lovell's failure to reclaim the Crowland fens. Draining of these wetlands would be resumed in the 1630s under the direction of a Dutch engineer, Sir Philibert Vernatti. His works were completed in 1637 but two winters later they were flooded again and were not made dry until a mechanical pumping station was installed at Pode Hole in 1827. In Jonson's age, the devices Fitzdottrel envisions, self-propelled ploughs and titanic windmills, would have sounded like ridiculous chimeras. Today, they can be seen to anticipate the tractors and hydro-engineering works that have converted the fens into lucrative farmland. Composed in that lag period when the vision of what applied science could perform outpaces the mechanical expertise required to achieve it, Jonson's play satirizes techno-optimism as magical thinking.

To situate the play in its ecological context is not to imply that The Devil is an Ass should be read as a straightforward pièce à clef. Engine bears little resemblance

${ }^{13}$ This connection was first made by in the seventeenth century by Margaret Cavendish in The Blazing World (2016, p. 104). 
to the grizzled and bookish magus Dee. Rather he and Merecraft might be taken as representatives of the mechanical-minded urban entrepreneurs to whom Dee addressed his Mathematical Praeface (Harkness, 2007, pp. 112-13). ${ }^{14}$ Nevertheless, the complex entanglement of magic and science in Dee's work also bedevils, as it were, Jonson's comedy. Dee believed applied technology could drain the fens and that engineers should not be tarred as conjurors; at the same time, he conducted séances to talk with angels. Fitzdottrel denies any diabolical agency in the fendraining; simultaneously, he conjures demons. The two mentalities are not mutually exclusive. Indeed, Jonson's comedy suggests the two were mutually reinforcing. His gullibility towards demons makes Fitzdottrel more inclined to believe in Merecraft and Engine's mechanical wonders. By linking the projectors with charlatans who fake demonic possession, the play discredits the fen drainage as a hoax. Jonson denounces capitalist techno-science as magical thinking fueled at bottom by greed. A similar moral underlies The Alchemist, but the ecological stakes in The Devil is an Ass are arguably even higher. Unlike alchemy, Dee's hydro-engineering was no pseudo-science. The last great wilderness in England was about to be wiped off the map. With its explicit cross-references to The Tempest, Jonson's comedy may even take a jab at Shakespeare's ode to the drainage in the wedding masque. Instead of encouraging the venture, Jonson bids James to repudiate the Crown's pacts with the undertakers and to spurn them with the same zeal he did fake demoniacs. ${ }^{15}$

When The Devil is an Ass was first printed in 1631 its satire was just as cutting as when it was first staged 15 years earlier. In 1629, Charles I had knighted the Dutch engineer Cornelius Vermuyden for reclaiming Hatfield Chase, so the satiric barbs hurled at the Dutch throughout the play would have been even more pointed. In 1630, the Earl of Bedford broke ground on the "Great Level" that would eventually drain the Great Fen straddling Norfolk and Cambridgeshire. These initiatives provoked resistance and gave Jonson's comedy a fresh topicality. Though he doubtless had long planned a second volume of his Works, by publishing the play at that moment Jonson was in effect intervening in public debate over the destruction of England's wetlands. ${ }^{16}$

Does this mean one could label The Devil is an Ass an "environmental text" avant la lettre? If that rhetorical question is fraught with difficulties, it is, nevertheless, worth asking. Although Jonson's play does not really meet the criteria for the label proposed by ecocritic Lawrence Buell, it does chastise human entitlement to exploit and radically transform the natural world, and adopts an activist stance-at

\footnotetext{
14 Donaldson proposes that Merecraft may have been based on Sir Arthur Ingram (2011, p. 340). The engineer William Englebert who collaborated with Lovell may have been a prototype for Engine.

15 Leah Marcus upholds this comedy as an attempt to enlighten James, "to show him his policies were being abused and reinforce his theoretical opposition to injurious monopolies" (1989, p.101). Her views are echoed by Margaret Jane Kidnie who sees it as evidence of the "politically engaged and sometimes even critical relationship of the poet to his king" (2000, p. xxiv).

16 The profits Bedford and the Killigrew family reaped from the fens would-as Julie Sanders notes fund the construction of Covent Garden, the hub of London's theatre district in the late seventeenth century, where The Devil is an Ass appears to have been revived in 1663 (2011, p. 26). See Happé (1994, p. 22).
} 
no small risk to the author's reputation-in condemning the state's environmental policies (Buell, 1996, pp. 7-8).In his celebrated "To Penshurst" and "To Sir Robert Wroth," Jonson praises the country house as a sustainable, local economy whose owners "dwell" with the land rather than remould and exploit it. By leaving his rural Norfolk estate and coming to London in pursuit of wealth and fashion, Fitzdottrel violates the ideals espoused in Jonson's pastoral poetry. It is, therefore, appropriate that the Jonsonian wits in the play strip him of his lands. To further clarify the environmental stakes of The Devil, this chapter has illustrated how demonology provided early moderns with a vocabulary for designating drastic interventions in the perceived natural order as unlawful. At the start of seventeenth century, the formidable task of draining the fens required importing advanced Dutch technology that the local population could castigate as demonic. As this technology was adopted and proven effective, its stigma gradually faded. The eventual destruction of the fens, then, may have played a modest part in the gradual widening of the rift between magic and science in the late seventeenth century. When Jonson wrote his comedy, however, these seams were still visible. Calling attention to these seams, Jonson invites his audience - appealing to the scepticism of the urban middling classesto laugh not only at provincial credulity but also at the hubristic presumption that humans can control the vast and unpredictable forces that shape the wetlands. If Jonson was wrong about the practicability of the drainage in the medium term, his intuition is being vindicated in the long term; the rising sea-levels on our warming planet are now re-wilding the fens.

By equating occult magic with technological dominion, and reading early modern texts through a modern ecological prism, this chapter may be accused of "writing history through metonymy" (Boehrer, 2013, p. 166). Though analysing metonymy in cultural discourse is precisely where literary critics have an advantage over historians, any ecocritical reading of early modern texts must be aware of the pit-trap of anachronism. It would be wishful thinking to claim that Jonson's satire is motivated by bio-centric concern for the non-human rather than hatred of human venality. In comparison to "Powte's Complaint," The Devil is an Ass does not entertain any thoughts about the rights of wildlife. However, the name Jonson chose for his dupe, Fitzdottrel, is significant in this regard: a type of plover, the dottrel is a wading bird and migratory resident of the fens. Unaccustomed to humans, plovers were easy prey for hunters. The name now seems a subtle reminder that the real victims of this environmental tragedy were-along with the rural poor-the wildlife whose habitat was destroyed. Insofar as Jonson's attack on the fen drainage is prompted by his loathing of human avarice rather than a love for the wildness of the wetlands, The Devil is an Ass at best promotes a shallow rather than a deep ecology. It is not clear that Jonson opposes land reclamation per se but only the unworkable and crooked schemes of his day, though his attitude may have resembled that of his beloved teacher, William Camden, who thought the failures of the current projects proof of their impiety. To conclude on a more cautious note, The Devil is an Ass would perhaps be more fairly categorized not as an environmental text but a techno-sceptical satire with environmental implications. That said, with the advent of ecocriticism in early modern studies, The Devil is an Ass no longer seems a minor work or "dotage." If it does not expose the ecocidal tendencies of capitalism with the clarity of 
Henrik Ibsen's Enemy of the People, it, nevertheless, arguably wades more boldly into the actual environmental politics of its day than any play in the canon of early English drama.

An early version of this article was presented in 2015 at the York Symposium on Magic in Intellectual History and at the Thomas Harriot Symposium at the University of Durham. I am grateful to Kevin Killeen and Stephen Clucas for their feedback and hospitality.

Open Access This article is licensed under a Creative Commons Attribution 4.0 International License, which permits use, sharing, adaptation, distribution and reproduction in any medium or format, as long as you give appropriate credit to the original author(s) and the source, provide a link to the Creative Commons licence, and indicate if changes were made. The images or other third party material in this article are included in the article's Creative Commons licence, unless indicated otherwise in a credit line to the material. If material is not included in the article's Creative Commons licence and your intended use is not permitted by statutory regulation or exceeds the permitted use, you will need to obtain permission directly from the copyright holder. To view a copy of this licence, visit http://creativecommons.org/licen ses/by/4.0/.

\section{References}

"Anonymous to Anonymous." March (1622). MS Secretaries of State: State Papers Domestic, James I, 16031640. SP 14/128 f.149. The National Archives of the UK. State Papers Online. Web. 11 Mar. 2016.

Ash, E. H. (2004). Power, knowledge, and expertise in Elizabethan England. John Hopkins University Press.

Ash, E. H. (2017). The draining of the fens: Projectors, popular politics, and state building in early modern England. John Hopkins University Press.

Balfour, M. C. (1891). Legends of the cars. Folklore, 2(2), 145-170.

Barrowclough, D. (2014). 'The wonderful discovery of witches': Unearthing the occult, necromancy and magic in seventeenth-century England. Academia.edu/7973344. Accessed 10 Feb 2015.

Boehrer, B. (2013). Environmental degradation in Jacobean Drama. Cambridge University Press.

Borlik, T. A. (2013). Caliban and the fen demons of Lincolnshire: The Englishness of Shakespeare's Tempest. Shakespeare, $9(1), 21-51$.

Borlik, T. A., \& Egan, C. (2018). Angling for the "powte": A Jacobean environmental protest poem. English Literary Renaissance, 48(2), 256-289.

Buell, L. (1996). The environmental imagination. Harvard University Press.

Camden, W. (1610). Britannia. Trans. Philemon Holland. London.

Cavendish, M. (2016). The blazing world. Broadview.

Clark, S. (1999). Thinking with demons: The idea of witchcraft in early modern Europe. Oxford University Press.

Clarke, A. C. (1962). Hazards of prophecy: The failure of imagination. Profiles of the Future, 6(36), 1.

Cless, D. (2010). Ecology and environment in European drama. Routledge.

Clucas, S. (2003). 'Wondrous force and operation': Magic, science, and religion in the Renaissance. In P. Berry \& M. Tudeau-Clayton (Eds.), Textures of Renaissance knowledge (pp. 35-57). Manchester University Press.

Clulee, N. (1986). At the crossroads of magic and science. In B. Vickers (Ed.), Occult and scientific mentalities in the Renaissance (pp. 57-72). Cambridge University Press.

Clulee, N. (1988). John Dee's natural philosophy: Between science and religion. Routledge.

Colgrave, B. (trans.) (1956). Felix's Life of Saint Guthlac. Cambridge University Press.

Cooper, C. H. (1861). Athenae Cantabrigiensis. (3 Vols.). Cambridge.

Cophenhaver, B. (1992). Did science have a Renaissance? Isis, 83(3), 387-407.

Dee, J. (1570). Mathematical Praeface to the Elements of Geometrie of Euclid. London.

de la Pryme, A. (1870). Diary. Andrews \& Co.

Donaldson, I. (2011). Ben Jonson: A life. Oxford University Press.

Dugdale, W. (1662). History of embanking and draining of the Fens. London. 
Dutton, R. (2000). Jonson's satiric style. In R. Harp \& S. Stewart (Eds.), The Cambridge companion to Ben Jonson (pp. 58-71). Cambridge University Press.

Eamon, W. (1983). Technology as magic in the late Middle Ages. Janus, 70(3-4), 171-212.

Evans, R. C. (1994). Jonson in the context of his time. Bucknell University Press.

Fortrey, S. (1685). History or narrative of the great level of the fens.

French, P. (1972). John Dee: The world of an Elizabethan magus. Routledge.

Gaskill, M. (2007). Witchfinders: A seventeenth-century English tragedy. Harvard University Press.

Goethe, J. W. (1994). Faust part two. (D. Luke, Trans.). Oxford University Press.

Greenblatt, S. (1988). Shakespearean negotiations. University of California Press.

Happé, P. (Ed.). (1994). The devil is an ass. Manchester University Press.

Harkness, D. (1999). John Dee's conversations with angels: Alchemy, cabala, and the end of nature. Cambridge University Press.

Harkness, D. (2007). The jewel house: Elizabethan London and the scientific revolution. Yale University Press.

H. C. (1629). A discourse concerning the draining of the fens. London.

Herford, C. H., Simpson, P., \& Simpson, E. (Eds.) (1925-52). Ben Jonson. (11 Vols.). Clarendon.

Hutton, R. (Ed.). (2016). Physical evidence for ritual acts, sorcery, and witchcraft in Christian Britain: A feeling for magic. MacMillan.

Kidnie, M. J. (Ed.). (2000). The devil is an ass and other plays. Oxford University Press.

Kuhn, K. G., et al. (2003). Malaria in Britain: Past, present, and future. Proceedings of the National Academy of Sciences, 100(17), 9997-10003.

Lindley, D. (1993). The trial of Frances Howard: Fact and fiction at the court of King James. Routledge.

Lindley, K. (1982). Fenland riots and the English Revolution. Heineman.

Marcus, L. (1989). The politics of mirth: Jonson, Herrick Milton, Marvell and the defense of old holiday pastimes. University of Chicago Press.

Marlowe, C. (1993). Doctor Faustus (D. Bevington and E. Rasmussen, Eds.). Manchester University Press.

Maynard, J. (1650). A picklock of the old fen project. London.

Mebane, J. (1989). Renaissance magic and the return of the Golden Age. University of Nebraska Press.

Norden, J. (1607). Surveyor's dialogue. London.

Parr, A. (Ed.) (2012). The devil is an ass. In Bevington, D., et al (Eds.), The Cambridge edition of the works of Ben Jonson (Vol. 4.). Cambridge University Press.

Porter, E. (1969). Cambridgeshire customs and folklore. Routledge.

Riggs, D. (1989). Ben Jonson: A life. Harvard University Press.

Rossi, P. (1968). Francis Bacon: From magic to science (S. Rabinovitch, Trans.). Chicago: University of Chicago Press.

Rotheram, I. D. (2013). The lost fens: England's greatest ecological disaster. The History Press.

Sanders, J. (1998). Ben Jonson's theatrical republics. MacMillan.

Sanders, J. (1999). The Sad Shepherd and the North Midlands. Ben Jonson Journal, 6(1), 49-68.

Sanders, J. (2011). The cultural geography of early modern drama. Cambridge University Press.

Shumaker, W. (1972). The occult sciences in the Renaissance: A study in intellectual patterns. University of California Press.

Shumaker, W., \& Heilbron, J. L. (Eds.) (1978). John Dee on astronomy. University of California Press.

Simmons, J. L. (1980). Diabolical realism in Middleton and Rowley's The Changeling. Renaissance Drama, $11,135-170$.

Stivers, R., \& Stirk, P. (2001). Technology as magic: The triumph of the irrational. Continuum.

Sullivan, H. (2011). Affinity studies and open systems: A nonequilibrium, ecocritical reading of Goethe's Faust. In A. Goodbody (Ed.), Ecocritical theory: New European approaches (pp. 243-255). University of Virginia Press.

Swanton, M., Knight, S., \& Ohlgren, T. (Eds.) (1997). Hereward the Wake. In Robin Hood and other outlaw tales. Medieval Institute.

Szonyi, G. (2010). John Dee's occultism: Magical exaltation through powerful signs. SUNY University Press.

Toffler, L. (1967). Lore and legend of the western fen borderland. Unpublished B. A. Thesis, University of Leeds, Institute of Dialect and Folk Life Studies. ACC No 653 SRP/2/001.

Thomas, K. (1971). Religion and the decline of magic. Oxford University Press.

Vickers, B. (1984). Occult and scientific mentalities. Cambridge University Press.

Wistman, R. S., \& McGuire, J. E. (1977). Hermeticism and the scientific revolution. Los Angeles: Nature.

Yates, F. (1964). Giordano Bruno and the hermetic tradition. University of Chicago Press.

Yates, F. (1979). Occult philosophy in the Elizabethan age. Routledge. 
Young, F. (2013). Witches and witchcraft in Ely: A history. Cambridge Print Solutions.

Publisher's Note Springer Nature remains neutral with regard to jurisdictional claims in published maps and institutional affiliations.

\section{Authors and Affiliations}

\section{Todd Andrew Borlik ${ }^{1}$}

$\bowtie$ Todd Andrew Borlik

t.borlik@hud.ac.uk

1 Department of English, Linguistics and History, University of Huddersfield, Queensgate, Huddersfield HD1 3DH, UK 